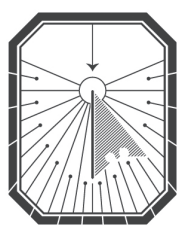

KYIV-MOHYLA

HUMANITIES JOURNAL

KYIV-MOHYLA SCHOLARLY PEER-REVIEWED JOURNALS

Ukrainian Investigative Journalists After the Euromaidan: Their Role Conceptions and Worldviews

Author(s): Oleksandr Yaroshchuk

Source: Kyiv-Mohyla Humanities Journal 7 (2020): 101-121

Published by: National University of Kyiv-Mohyla Academy

http://kmhj.ukma.edu.ua/ 


\title{
Ukrainian Investigative Journalists After the Euromaidan: Their Role Conceptions and Worldviews
}

\author{
Oleksandr Yaroshchuk \\ National University of Kyiv-Mohyla Academy, \\ Mohyla School of Journalism
}

\begin{abstract}
In recent years, an increased interest in journalistic roles has inspired multiple empirical studies aimed at establishing the journalistic role conception and performance of journalists worldwide. Ukraine is not an exception. Studies published in recent years show that the professional culture of journalists in Ukraine is changing, resulting in the "blurring of boundaries" between journalism and activism. Moreover, Ukrainian journalists also show a high degree of political engagement. However, these studies have not measured the specific professional settings of investigative journalists, who form a unique community in the Ukrainian media system. Therefore, this study is devoted to uncovering the role conceptions of Ukrainian investigative journalists, their professional identities, and culture. The results show that many journalists express multiple roles: a "populist mobilizer" combined with "watchdog" role, or "watchdog" combined with "critical change agent" role. This confirms the hypothesis that a multiplicity of roles and blurring of boundaries are also present among investigative journalists.
\end{abstract}

Key Words: Investigative journalism, role conceptions, professional culture, watchdog journalism, journalism in Ukraine, Euromaidan.

\section{Introduction}

Ukraine has experienced serious political, economic, and legal changes and challenges in the past 3 o years. Since Ukraine regained its independence, it has been haunted by its Soviet legacy, which defined, among other things, its media system, journalist education, and the professional culture of journalists, including the role of media in society. The changes sped up after the Euromaidan Revolution of winter 2013-2014, which resulted in the ousting of President Victor Yanukovych, the election of a new president, as well as the ratification of an Association Agreement with the EU. Additionally, several important databases and registers, such as the procurement system, e-declarations of officials, the land cadaster and others, were opened by the authorities, facilitating the work of journalists. The above mentioned developments have changed the reality in which Ukrainian journalists live and work. Almost immediately after the media 
climate improved, new investigative projects appeared on national and regional levels. Unlike at private media companies, they were launched by journalists themselves and financed either by the people via crowdfunding initiatives or by grants that became available to journalists in large numbers.

This new media reality shaped the journalistic community and individual journalists' perceptions of themselves as a separate caste of professionals, whose role is often described in terms of a "fourth estate" or "watchdog." But what exactly do investigative journalists think of themselves? How do they perceive their roles in media and society? What do they think about themselves and the roles they perform? To answer these questions it is useful to consider the journalistic role conceptions theory. Toward this end, this article explores the role conceptions of Ukrainian investigative journalists. It focuses on how Ukrainian investigative journalists with differing backgrounds and career circumstances perceive their roles in the complex Ukrainian media context after the Euromaidan, amidst war in Eastern Ukraine, and political and economic turmoil. The article concludes this overview with a discussion of the main types of role conceptions shared by Ukrainian investigative journalists.

\section{A Theoretical Framework}

The theory of professional journalistic roles has been an important study concept for scholars worldwide. A great number of researchers over the past five decades have developed an idea into a meaningful concept that is used to determine and analyze a broad range of issues, namely: what roles journalism performs in society, how they change over time, how journalism culture, daily routines, and other factors influence media performance and how journalism, as a profession, is conceptualized by journalists themselves. ${ }^{1}$

Journalistic role conception is a useful instrument for understanding how journalists see their mission. ${ }^{2}$ It forms a bridge between journalism as a profession, with its values, patterns, templates, and philosophy, and an individual journalist with his/her self-perception of the world around.

In literature, role conceptions are also often described as "ideologies" and "value orientations," ${ }^{3}$ or as functions journalism is associated with. ${ }^{4}$ This ambiguity of terminology complicates the study of the phenomenon and erodes the boundaries between different elements of a hierarchical system of journalism's philosophy and

Thomas Hanitzsch et al., "Mapping Journalism Culture Across Nations," Journalism Studies 12.3 (2011): 273-93; David Weaver and Lars Willnat, "The Global Journalist in the Twenty-First Century," Journalism Practice 7.2 (2013): 163-83.

2 Thomas Hanitzsch, "Deconstructing Journalism Culture: Toward a Universal Theory," Communication Theory 17.4 (2007): $367-85$. Tim Vos, “Journalistic Role Conceptions: A Bridge Between the Reporter and the Press," paper presented at the International Communication Association's Conference, New York, May 2005. Seth C. Lewis, "The Tension Between Professional Control and Open Participation: Journalism and its Boundaries," Information, Communication, and Society 16.6 (2012): 1-31. 
culture. From this standpoint, journalistic roles are individual expressions of professional reality and basic forms of adaptation to everyday journalistic habitus. Taking an inductive approach, a more overarching hierarchy than journalistic role can be developed.

In the first place, journalism's self-perception is structured around templates. These patterns of how things are done are crucial for news-making and the production of other journalistic output as they simplify the work media professionals do, but, as argued by Michał Krzyżanowski, they also "construct [and] structure media discourse, $[\ldots]$ the ways in which journalism professionals perceive themselves and others in the process of journalistic work." ${ }^{5}$ Templates, thus, are not only guidelines that facilitate news-making, but also instruments for identifying and distributing journalistic roles as an indispensable element of journalism culture inside the community of journalists.

In its turn, the journalistic template is based on "the value-laden discourse about journalistic principles and ethics that can [...] be seen as a form of a recurrent construction of a "professional-mythology of journalism."' 6 Values that help to sustain journalistic patterns are examples of what Bourdieu called "deep-seated dispositions"; they "help [to] construct imagined rather than de facto practices and identities," leading to identifying what's on the mind rather than in practice. ${ }^{7}$

Normative values expressed in journalistic role conceptions play a crucial role in determining journalists' professional identities. ${ }^{8}$ Using normative "ideologies," journalists distinguish their role from roles played by other members of society. By adhering to professional ideology, journalists follow "the values, orientations and predispositions" that journalism as a profession holds on a macro-level. ${ }^{9}$ Mark Deuze defines journalism's professional ideology as the "dominant way in which 'news people' validate and give meaning to the context in which they work." 10

However, the strongest connection role conceptions have is with journalistic professional culture, which predetermines journalists' approaches towards media as a profession and, thus, is a chief factor in determining the essence of normative and cognitive roles. Journalistic culture is usually defined as "the way journalists think and act," "a set of ideas and practices by which journalists, consciously and unconsciously, legitimize their role in society and render their work meaningful for themselves and others." 11 Journalism culture is one of the essential ingredients that defines and influences the worldviews of journalists and their role perceptions.

6 Krzyżanowski, "Values, Imaginaries, and Templates of Journalistic Practice," 346.

7 Krzyżanowski, "Values, Imaginaries, and Templates of Journalistic Practice," 347.

8 Mark Deuze, "What is Journalism? Professional Identity and Ideology of Journalists Reconsidered," Journalism 6.4 (2005): 442-64. Thomas Hanitzsch, "Mapping Journalism Culture: A Theoretical Taxonomy and Case Studies from Indonesia," Asian Journal of Communication 16.2 (2006): 169-86.

Deuze, "What is Journalism," 446. Hanitzsch, “Deconstructing Journalism Culture," 367-85. 
According to a typology developed by Thomas Hanitzsch, journalism culture is enacted on three levels: cognitive, evaluative, and performative. He further proposes to divide journalism culture into "three essential constituents" - institutional roles, epistemologies, and ethical ideologies — and "seven principal dimensions" interventionism, power distance, market orientation, objectivism, empiricism, relativism, and idealism. The three constituents embrace "the shared values" or "collective conscience for the profession"12 that journalists have, which define journalism's identity in a cultural context.

The first constituent in this classification - institutional roles - represents the "normative and actual functions of journalism in society," describing responsibilities of the media and its role in informational space. Institutional roles are further divided into three dimensions that respond to the following questions: how detached journalism is, how close it positions itself are to centers of power, and what type of audience it serves.

The first dimension - interventionism - distinguishes between two types of journalism that are opposite to each other-interventionism and detachment. Interventionists, also referred to as "participants," "advocates," or "missionaries," 13 have an active stance towards their reporting. They engage and persuade. They believe they have the power to influence events through critical reporting, getting involved, and producing change. Detached journalists, on the contrary, believe they must act as "disinterested transmitters of the news," 14 who help information to flow freely between different layers in society: horizontal and vertical alike.

The second dimension of the institutional roles constituent describes journalism's position toward loci of power and answers the question of whether journalism is loyal to or critical of the center of power. Its critical spectrum is best described as watchdog journalism, defined in literature as an "objective, factual, and critical reporting style"15 that "carries out an investigative and watchdog role on behalf of the public" 16 and serves

12 Hanitzsch, “Deconstructing Journalism Culture," 380.

13 For example: Bernard C. Cohen, Press and Foreign Policy (Princeton, New Jersey: Princeton University Press, 1963), 17-53; Wolfgang Donsbach and Thomas E. Patterson, "Political News Journalists: Partisanship, Professionalism, and Political Roles in Five Countries," in Comparing Political Communication: Theories, Cases, and Challenges, eds. Frank Esser and Barbara Pfetsch (New York: Cambridge University Press, 2004), 251-70; Morris Janowitz, "Professional Models in Journalism: The Gatekeeper and the Advocate," Journalism Quarterly 52.4 (1975): 618-26; Renate Kocher, "Bloodhounds or Missionaries: Role Definitions of German and British Journalists,"

European Journal of Communication 1 (1986): 43-64.

14 Hanitzsch, "Deconstructing Journalism Culture," 372.

15 Jebril Neil, "Is Watchdog Journalism Satisfactory Journalism? A Cross-National Study of Public Satisfaction With Political Coverage," Working paper, Reuters Institute for the Study of Journalism, University of Oxford, 2013, accessed March 15, 2020, https://reutersinstitute. politics.ox.ac.uk/our-research/watchdog-journalism-satisfactory-journalism-cross-nationalstudy-public-satisfaction.

16 Silvio Waisbord, Watchdog Journalism in South America (New York: Columbia University Press, 2000). 
the role of "the public's eyes and ears." ${ }^{17}$ Loyal journalists carry out a "propagandist role" and practice "agitator journalism"; they serve as "mouthpieces of government or party." It is believed that journalists embracing the loyal role do not question official statements and party policy - they simply act as transmitters of the official position.

Market orientation is the third dimension of the institutional roles constituent. Whereas power distance shows how detached journalists are, market orientation serves to establish journalism's role in satisfying the public's information needs: news and hard analysis versus entertainment and lifestyle content. ${ }^{18}$ Respectively, journalism can address the needs of either the citizenry or consumers. The first group of journalists provides citizens with the information they need to make the political decisions necessary in a democratic order. By providing vital political information, journalism helps the people to take an active part in public life. When journalists are guided by a marketplace logic, they provide their audience with practical information that should help to resolve daily issues and to entertain.

Differences in journalist role typologies stimulated attempts to establish one overarching system of roles. Clifford Christians et al. propose the following structure of roles: monitorial, facilitative, radical, and collaborative. First, journalists collect, publish, and distribute information in the interest of the public (the monitorial role). Second, they promote dialogue in society and provide space for different ideas (the facilitative role). Third, they support change by providing a milieu for critical voices (the radical role). Fourth, they defend and support official policies (the collaborative role). ${ }^{19}$

According to Hanitzsch, journalistic roles are articulated and enacted on two distinct levels: role orientations (normative and cognitive) and role performances (practiced and narrated). Hanitzsch defines role orientations as "discursive constructions of the institutional values, attitudes, and beliefs concerning the position of journalism in society." ${ }^{20}$ Normative and cognitive role orientations share "attitudinal features," but have substantial differences: whereas normative roles explain what is desirable to think, or to do, in a given context, cognitive roles show what journalists want to do. ${ }^{21}$ Role preferences, on the contrary, describe the behavioral dimension of journalistic roles, i. e. how journalists perform their duties. In general, role conceptions correspond to the first level—role orientations and cognitive roles, developed by Hanitzsch.

Sheila S. Coronel, "Corruption and the Watchdog Role of the News Media," in Public Sentinel:

News Media and Governance Reform, ed. Pippa Norris (Washington, D.C.: World Bank, 2010), 111-37.

18 Hanitzsch, "Deconstructing Journalism Culture," 374.

19 Clifford G. Christians et al., Normative Theories of the Media:Journalism in Democratic Societies (Chicago: University of Illinois Press, 2009).

20 Thomas Hanitzsch, "Professional Identity and Roles of Journalists," Oxford Research Encyclopedia of Communications, October 26, 2017, https://doi.org/10.1093/ acrefore/9780190228613.013.95.

21 Vivien Schmidt, "Discursive Institutionalism: The Explanatory Power of Ideas and Discourse," Annual Review of Political Science 11.1 (2008): 303-26. 
He then distinguishes four types of roles: detached watchdog, populist disseminator, critical change agent, and opportunist facilitator. ${ }^{22}$ The first group see themselves as watchdogs of the powerful and believe that their role is to provide citizens with political information. Populist disseminators emphasize the journalist's information gathering and dissemination function. Critical change agents advocate for social change and set the political agenda. Opportunist facilitators serve as partners of the state or ruling government.

However, while discussing journalistic role conceptions we should remember that they "do not grow in a vacuum." ${ }^{23}$ Role conception is a popular research topic due to the assumption that "journalists' role conceptions influence their work." 24 As a result, scholars receive a valuable tool for measuring relations between conceptions and media culture.

\section{Journalistic Roles in the Ukrainian Context}

The post-Soviet legacy coupled with the absence of an independent media market had a great influence on the professional culture of Ukrainian journalists during the first two decades following Independence. As suggested by Natalya Ryabinska, the redistribution of media from state to private ownership led to "media capture" by the state and private business. 25 "Media capture" exemplified itself in the following patterns: concentrated ownership, indirect control using informal techniques, nontransparent media ownership structures, and close ties with politics. Consequently, Ukrainian journalists had to adjust to a new center of power - the private interestand this adjustment, in turn, influenced the construction of journalist identity.

Resulting from the concentration of media outlets, "censorship induced by authorities" was substituted by "money censorship," wherein media moguls, a newly created class of financial-political elites, control mainstream media outlets and direct their editorial processes. Moreover, Ukrainian media transmuted into "factories providing paid PR services." ${ }^{26}$ Ukrainian elites manipulated the media using them as

22 Thomas Hanitzsch, "Populist Disseminators, Detached Watchdogs, Critical Change Agents and Opportunist Facilitators: Professional Milieus, the Journalistic Field and Autonomy in 18 Countries," International Communication Gazette 73.6 (2011): 477-94.

Paolo Mancini, "Political Complexity and Alternative Models of Journalism," in De-Westernizing Media Studies, eds. J. Curran and Myung-Jin Park (London; New York: Routledge, 2000), 234-35.

Arjen van Dalen, Claes de Vreese, and Erik Albaek, "Different Roles, Different Content? A Four-Country Comparison of the Role Conceptions and Reporting Style of Political Journalists," Journalism 13.7 (2012): 903-22.

25 Natalya Ryabinska, "Media Capture in Post-Communist Ukraine," Problems of Post-Communism $61.2(2014): 46-60$.

26 Otar Dovzhenko, "Ukrainski media siohodni: z haremu v bordel [Ukrainian Media Today: From Harem to Brothel]," Detector Media, May 26, 2008, https://detector.media/withoutsection/ article/386o2/2008-05-26-ukrainski-media-sogodni-z-garemu-v-bordel/. 
instruments of political pressure. ${ }^{27}$ The Ukrainian media system became a classical example of a contemporary heteronomous journalistic field wherein structure prevails over the agency.

Substantial changes were provoked by the Euromaidan revolution in winter 2013-2014. As a result of the political turmoil, which also affected the journalism field, two dominant groups of professional journalists emerged: the activists and the conformists. ${ }^{28}$ The activists perceive themselves as reformers. They are actively involved in political life and contribute to progressive change. On the contrary, the conformists adhere to the traditional journalistic role of disseminating public information. However, during the Euromaidan, it became evident that media with an activist position do not limit themselves to advocating for change and even substitute for the state and "fulfill the functions traditionally associated with public authorities." 29 For instance, media began fulfilling "surveillance and policing functions"; investigative journalism made state institutions "incapacitated." 30

Although journalists' involvement with events on Euromaidan was a particularly strong phenomenon, the political engagement of journalists in Ukraine is a longstanding tradition:

In East-Central Europe the role of the journalist has traditionally been regarded more as a political activity than as a content producer or manufacturer of "objective" news for the market. The traditional role of a journalist has been closer to that of an intellectual, artist, or writer - someone who spoke on behalf of the people and to the people. ${ }^{31}$

Joanna Szostek writes that a striking feature of the Euromaidan was "the blurring of boundaries between journalism and activism, between media professionals and civil society." 32 The journalistic community played an active role in directing the protests and providing media coverage. During the Euromaidan journalists served "as the political opposition hub and coordinating platform." Media, according to Tomasz Goban-Klas, became observers, promoters, amplifiers, and organizers. ${ }^{33}$ Even the first protest on

27 Dariya Orlova, "Ukrainian Media After the EuroMaidan: In Search of Independence and

Professional Identity," Publizistik 61.4 (2016): 441-61.

Horbyk, "In Pursuit of Kairos," 6.

Inka Salovaara-Moring, "Beyond East and West: Alternative Spheres of Journalism, Capitalism and Public," in Manufacturing Europe: Spaces of Democracy, Diversity and Communication, ed. Inka Salovaara-Moring (Gothenburg: Nordicom, 2009), 99. 
Maidan on November 21, 2013, convened after a Facebook post by well-known journalist Mustafa Nayyem. ${ }^{34}$

When the revolution was over, Serhii Leshchenko, Mustafa Nayyem, Tetiana Chornovol, and Yehor Sobolev, who previously claimed to be watchdogs, became MPs. But their transition from journalism to politics never took place. As a result, deep and substantial conflicts of interest emerged, blurring lines not only between journalism and activism, as was the case during the Euromaidan, but also between journalism and politics, which possess opposite identities and professional cultures..$^{35}$

After the Euromaidan, interventionism became "a distinctive feature of journalism culture." ${ }^{36}$ The research found that journalists regarded themselves either as "drivers of change" or as "collaborators," who defend the interests of the state in a situation of a political vacuum and external hybrid aggression.

The "blurring of boundaries" and an increased activist position of many journalists during and after the Euromaidan provoked tensions between two identities professional and civic. Anhelyna Kariakina, a political journalist from Hromadske TV, described this conflict in the following way:

In Ukraine, a journalist is more than just a journalist. In any society, due to various reasons, journalists have more information than common citizens, but in Ukraine, journalists have become a driving force of change: they push for passing laws, for investigations to be held. We recognize that we sometimes do more than we would have to do in a society that lives according to the principles of the rule of law. But there is a borderline as well. ${ }^{37}$

This tension between the two poles had already demonstrated itself during previous revolutions and political unrest, such as the 2004 Orange Revolution. The role of journalists in the latter was so important that media experts Nataliia Lihachova and Lesia Hanzha called it the "Journalistic Revolution." 38

34 Mustafa Nayyem, "Ladno, davaite seriozno...[Okay, Let's Take it Seriously...]," Facebook, November 21, 2013, https://www.facebook.com/Mefistoff/posts/1020117728026o151?stream_.

35 Serhiy Kvit, “Ukraine Has Never Given Up and Never Will," Kyiv Post, February 1, 2020, https:// www.kyivpost.com/article/opinion/op-ed/serhiy-kvit-ukraine-has-never-given-up-and-neverwill.html.

36 Halyna Budivska and Dariya Orlova, "Between Professionalism and Activism: Ukrainian Journalism After the Euromaidan," Kyiv-Mohyla Law and Politics Journal 3 (2017): 137-56.

37 Maryna Dovzhenko, "Ne boiatysia siroho vovka: hromadianskyi mediaaktyvizm v Ukraini [Not to be Afraid of a Grey Wolf: Civic Media Activism in Ukraine]," School of Journalism at the Ukrainian Catholic University, December 15, 2015, http://web.archive.org/web/20160121102942/ http://journalism.ucu.edu.ua/program-highlights/4615/.

38 Olena Kholodenko, "Nataliia Ligachova: 'Samaia opasnaia zavisimost segodnia dlia zhurnalista — eto zavisimost ot sobstvennykh ubezhdenii' [Nataliia Ligachova: 'The Most 


\section{Research Question and Methodology}

The latest bulk of research on journalistic roles has shown "the urgent need" to expand the research of journalistic roles beyond the West. ${ }^{39}$ Consequently, to fill in this research gap, we begin by analyzing role conceptions of Ukrainian journalists. More precisely, this research was motivated by the following research question: What are the main role conceptions of investigative journalists in Ukraine? Further, it aims at analyzing the following three hypotheses. First, that Ukrainian investigative journalists give preference to the watchdog role of the press $\left(\mathrm{H}_{1}\right)$. Second, that investigative journalists have interventionist attitudes rather than those of disseminators and try to play an active role in political life as "agents of change" (H2). Third, that investigative journalists from the regions have a stronger critical stance than do journalists from national outlets $\left(\mathrm{H}_{3}\right)$.

The study is based on semi-structured, in-depth interviews with 15 Ukrainian investigative journalists and a survey of 20 investigative journalists, conducted in January-April 2019. The interview sample includes media practitioners with diverse experience and education, staff journalists and freelancers, TV and print reporters, journalists from national (8) and regional (6) outlets. Nine are from independent outlets, three from TV channels, and two work in print media. The participants were selected on the basis of the author's prior knowledge of the field, with the help of the snowball sampling technique.

As a method, the interview helps to elicit the discourse of self-perception from journalists. It reveals the roles media perform and also their imagined roles. For instance, Deuze points out that discourse about how journalists give meaning to their work is a way of "constantly negotiating their professional identity with elements of structure (the context in which they work) and subjectivity (what they bring to the job)." ${ }^{40}$

Given the qualitative nature of the study, we aimed at identifying how investigative journalists conceive their roles, what the most common role conceptions are, and how role conceptions differ among different groups of investigative journalists. The size of the sample does not allow to generalize the findings. However, the study's goal was to identify the perceived roles of investigative journalists and the factors that define their professional culture.

Dangerous Addiction for a Journalist Today is Dependence on Their Own Beliefs]," Detector Media, December 20, 2017, accessed December 4, 2020, https://detector.media/community/ article/133264/2017-12-20-natalya-ligacheva-samaya-opasnaya-zavisimost-segodnya-dlyazhurnalista-jeto-zavisimost-ot-sobstvennykh-ubezhdenii/.

39 David Weaver, Lars Willnat, and Cleveland Willhoit, "The American Journalist in the Digital Age: Another Look at U. S. News People," Journalism \& Mass Communication Quarterly 96 (2019): 101-30; Claudia Mellado and Arjen van Dalen, "Changing Times, Changing Journalism: A Content Analysis of Journalistic Role Performances in a Transitional Democracy," The International Journal of Press/Politics 22 (2017): 244-63. 
The journalists were asked about their motivations for working in investigative journalism, their views about the role of journalism in general and investigative journalism in particular, the reasons behind their outlooks, as well as a range of specific questions concerning different aspects of their everyday activities. They were also asked about acceptable ways of receiving information, the boundaries of investigative journalism, their individual struggles, how newsroom decisions influence their role conceptions and stories they produce, as well as questions concerning their engagement in social activism and political life.

\section{Results}

Analyzing the interviews, it appears that Ukrainian investigative journalists possess differing, sometimes contradicting, role conceptions. On the one hand, they perceive themselves as disseminators of publicly relevant information, such as about government corruption, but on the other hand, they give priority to analyzing activities of the authorities, investigating and revealing. At some points, they become ambassadors of change, arguing for structural reform.

The following are the most frequently cited roles, adapted to correspond to the role conceptions typology developed by Hanitzsch.

\section{Populist Disseminators}

The interviewed journalists prefer the populist disseminator role. Below is an example:

The main function of a journalist is to communicate information. I think that investigative journalism in Ukraine has the same function as in other countries: that is, to inform, to find, to show what is hidden (N 6). ${ }^{41}$

An investigative journalist is a journalist that has the same role and function as other journalists. This particular journalist believes that "to communicate information" is what investigative journalists must do. However, investigative journalism shows an important criterion that differentiates it from conventional journalism, namely that there is hidden information, something that needs to be researched. Whereas conventional journalism is "based on a necessary minimum of information," investigative journalism is impossible without the maximum amount of information.

Investigative journalism is the journalism of facts. I'm talking about what I found as an investigative journalist ( $\left.\mathrm{N}_{4}\right)$.

$41 \quad$ Here and after "N" stands for "a journalist from a national media outlet"; "R" stands for "a journalist from a regional media outlet." 
However, investigative journalists underline that there are many nuances pertinent to this role. When deciding what topic to choose, investigative journalists should pay attention to its importance and relevance at a given moment. A journalist tells readers about "points of injustice" and informs them about rules that are being violated or improperly functioning rules. Investigative journalists have a responsibility to inform society about publicly relevant events.

(An) Investigative journalist comes into play when one of these three points is evident: someone has violated the rules, the rules work for someone specifically, or the rules are forgotten, and this negatively affects society. The journalist should screw in a lightbulb and turn the light on in the darkroom. Society should then decide what to do next and how to solve the problem ( $\left.\mathrm{N}_{4}\right)$.

In this case, investigative journalists play a vital role in political discourse. They serve as transmitters of information important to readers. However, this role is limited: investigative journalists only show a problem, society must then deal with it.

We, as investigative journalists, say that there is a problem, we inform and scream. But then law enforcement, deputies, and government must react. A journalist should inform, all others should react $\left(\mathrm{N}_{4}\right)$.

The journalist quoted above points out that the key role of investigative journalism is to inform and to expose. Sometimes it also educates people by providing them the information they need as citizens. This definition of the journalistic role excludes more activist-driven approaches, whereby journalists allow themselves to become involved in the processes they expose.

In a survey, eleven journalists mentioned that it is extremely important to provide people with the information they need as citizens:

How important is it to provide people with the information they need as citizens?

Extremely important

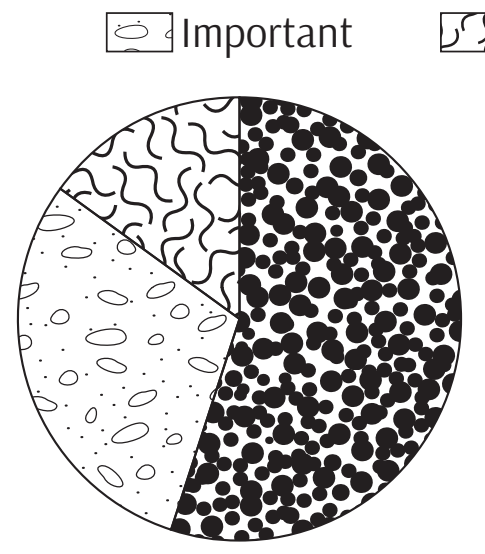
resy More important than not 
Thus, many investigative journalists in Ukraine agree that the populist disseminator role, which is to disseminate publicly relevant information, to be important.

\section{Detached Watchdogs}

If we talk about investigative journalists, their main purpose is to expose corrupt processes that are in the shadows and would not come to light without a journalist. Investigative journalists turn the light on and show hidden information. The main objective is to expose this person. The latter has to bear responsibility for the actions if the illegal actions are confirmed $\left(\mathrm{N}_{1}\right)$.

The quoted journalist believes that the primary role of investigative journalism is to expose and reveal information hidden by someone. Only at the second stage, when the information has been revealed, it is shared with society. Moreover, by revealing hidden information, journalists want to expose a person who committed an illegal act.

In the survey, 19 participants out of 20 agreed that "to control and oversee activities of the government" is extremely important. In their written responses, the journalists mentioned that they believe that their role is to "expose negative corruption phenomena" as well as "to talk about injustice and show who is guilty."

Support of investigative journalism's watchdog role
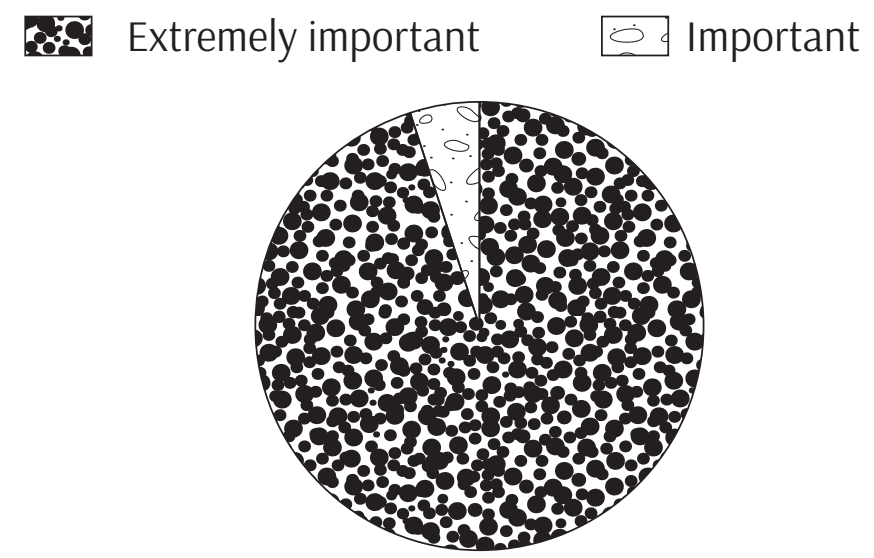

However, this only applies to politics. When asked about journalism's watchdog role over business, the journalists' responses changed:

- extremely important -3 responses;

- important-6 responses;

- more important than not-10 responses;

- I don't know -1 response. 


\section{Investigative journalism's business watchdog role}

Extremely important Mlmportant gMore important than not don't know

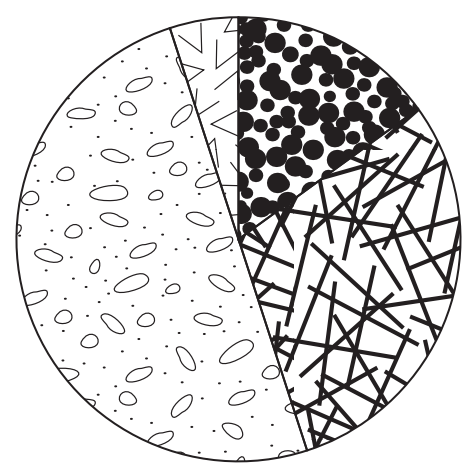

Even though the watchdog role is what many journalists believe to be the key function of the media, some journalists do not believe in the power of journalists to perform a watchdog role in Ukraine. One journalist calls investigative journalists "watchcats," who scream at wrongdoers until they are expelled or satisfied with minor concessions.

\section{Critical Change Agents}

According to Hanitzsch, critical change agents believe in the power of journalists to affect change and set the agenda. They see the role of journalism in advocating for social change, progress, and development. One Ukrainian investigative journalist, working on a national investigative project, believes that investigative journalism can also influence the decision-making process:

This is the most important thing. Nothing can exist on its own. It does not make sense to write articles for yourself. That's why every investigation is done to change the situation. Since almost all investigations are about negative factors, the main aim is to eliminate the negative factor, to punish the person that allowed it to happen (N 8).

The activist approach to the journalistic role is popular among investigative journalists. Many of them (40\%) believe that it is important to popularize reforms. 
Is it important for investigative journalists to popularize reforms, political and social changes?

Extremely important

GNot very important

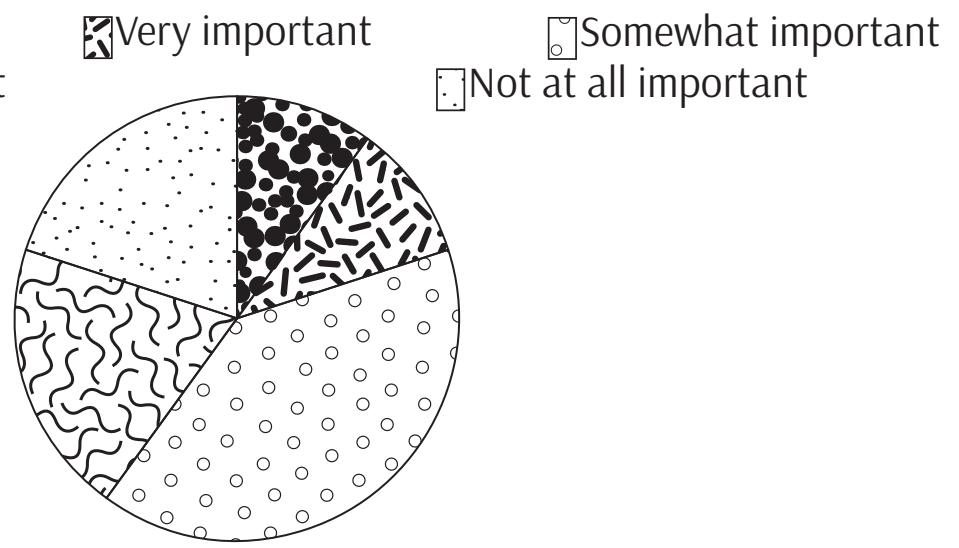

$45 \%$ agree that it is also important to influence public opinion.

How important is it for investigative journalists to influence public opinion?

Extremely important

b. Somewhat important

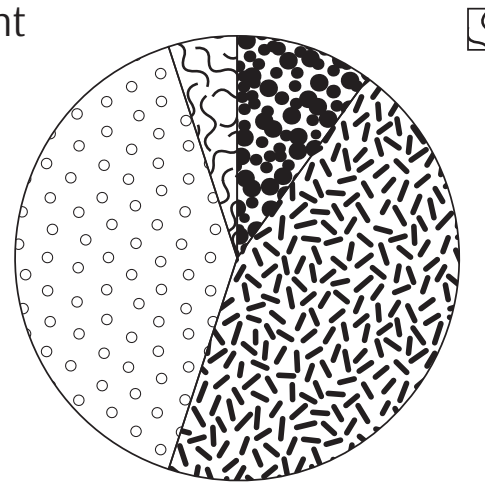

Journalists also believe it is important to encourage citizens to take part in political and social life.

Is it important for investigative journalists to encourage citizens to take part in political and social life?

Extremely important (GNot very important
Tig Very important (द) Not at all important 


\section{Opportunist Facilitators}

Because of the nature of their media genre, investigative journalists are reluctant to cooperate with the government. However, journalists admit that they may cooperate with law enforcement agencies when necessary, to bring public attention to issues or assist in seeking information. A journalist from a national outlet mentioned the following:

The role of a journalist is to help the legal process. If journalists join an investigation before proceedings are launched, they can interact with official investigators. They can help to collect information. I was often asked to do this. They told me: "You can send a request for access to public information and we cannot do this" (N 4).

In their responses, interviewed journalists mentioned other tasks that they may perform. One of them is to educate and to moderate. For instance, investigative journalists provide publicly important information and, in this respect, inform society about wrongdoings that happen in the public sphere.

Investigative journalism also moderates the discussion of important issues and allows a forum for different voices, especially those that do not receive enough attention from other media genres. Investigations often include "human interest stories," giving a voice, for instance, to victims. This shows that investigative journalism can play a more active role: to show the participants of a public debate and their opinions, to verify information, and to point out deficiencies in the public sphere.

\section{Role Change Under the Influence of External Factors}

Another important factor is that the roles of investigative journalists are not necessarily static. They may change under the influence of many factors. Not only journalistic roles influence how an investigation is done, but different external factors also define how roles are shaped.

Very often journalism is attracted by financial gain. Investigative journalists can raise important topics, but these are dictated not by professional choice, but by the availability of money. This is not an ideal situation. It turns out that media society is easy to manipulate $\left(\mathrm{N}_{7}\right)$.

In Ukraine, funding often defines what a journalist may write, consequently, journalists try to adjust their plans to the requirements of donors or private investors. 
Table 1. Role conceptions of the interviewed Ukrainian investigative journalists (according to Hanitzsch's classification) ${ }^{42}$

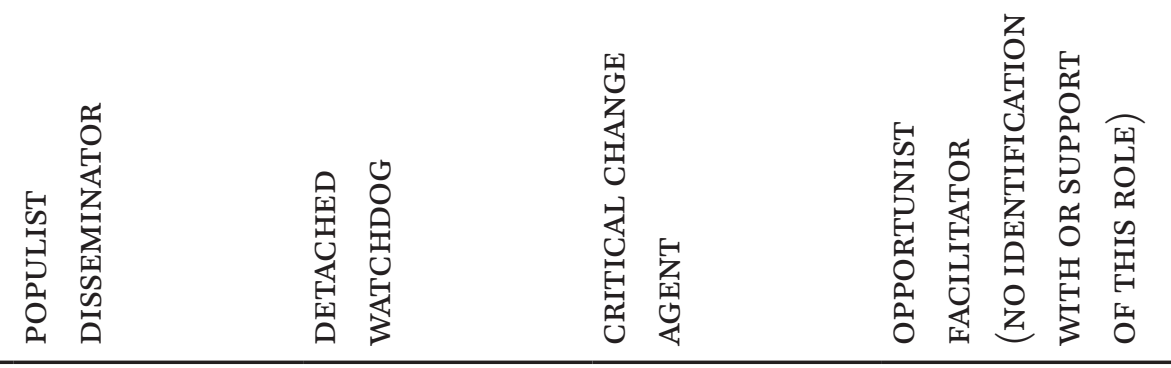

\begin{tabular}{|c|c|c|c|}
\hline $\mathrm{N}_{1}$ & & + & + \\
\hline $\mathrm{N}_{2}$ & + & & \\
\hline $\mathrm{N}_{3}$ & + & & \\
\hline $\mathrm{N}_{4}$ & + & & \\
\hline $\mathrm{N}_{5}$ & + & + & \\
\hline N 6 & + & & \\
\hline $\mathrm{N}_{7}$ & + & + & + \\
\hline N 8 & & + & + \\
\hline $\mathrm{N}_{9}$ & + & & \\
\hline $\mathrm{R}_{1}$ & + & + & + \\
\hline $\mathrm{R}_{2}$ & + & & \\
\hline $\mathrm{R}_{3}$ & & + & \\
\hline $\mathrm{R}_{4}$ & + & + & \\
\hline $\mathrm{R}_{5}$ & + & & \\
\hline R 6 & + & + & \\
\hline
\end{tabular}

\section{Discussion and Conclusions}

The research was guided by one major research question, namely that of what role conceptions prevail among investigative journalists in Ukraine. Moreover, three hypotheses were formulated based on previous research and expectations. These hypotheses are:

- Ukrainian investigative journalists give preference to the watchdog role of the press $(\mathrm{H} 1)$.

- Investigative journalists have interventionist attitudes rather than disseminator ones and try to play an active role in political life as "agents of change" $(\mathrm{H} 2)$.

- Investigative journalists from the regions have a stronger critical stance than do journalists from national outlets $\left(\mathrm{H}_{3}\right)$.

To arrive at these conclusions, 15 journalists were interviewed. Additionally, 20 journalists responded to a survey.

42 The table indicates that journalists tend to combine their perceived roles and not give preference to one or another. 
The results show that no hypothesis was confirmed. First, although the watchdog role is important, journalists prefer the "populist disseminator role." Second, the disseminator attitude is more common than the interventionist one. Journalists, at least when they talk to a researcher, do not agree with the statement that journalists take active roles. Third, there is no substantial difference in role interpretation between journalists from national and regional media outlets.

Contrary to what was expected, another important feature of Ukrainian investigative journalism and the media system was revealed. In particular, it was found that for many journalists there is no single preferable role conception. It became evident that under different circumstances role conceptions may change, usually from populist mobilizer to watchdog (occasionally to critical change agent) and vice versa. This said, it may be concluded that there is a multiplicity of role conceptions, which, at certain points, is further transformed into a blurring of boundaries when journalistic roles are transformed into activist ones. For instance, Szostek earlier found that after the Euromaidan, boundaries between journalism and activism and between journalists and civil activists have blurred..$^{43}$ There are no more boundaries between the three most shared role conceptions - populist mobilizer, watchdog, and critical change agent. The opportunist facilitator role is not present among investigative journalists in Ukraine.

Second, it was discovered that investigative journalists prefer to define their roles either as those of populist mobilizers or watchdogs. These two role conceptions remain the most shared among investigative journalists. The blurring of boundaries was earlier witnessed among Ukrainian journalists during the Euromaidan revolution. In this instance, two roles were identified: activist and conformist. ${ }^{44}$ The activists are more involved in political life and have a more critical attitude towards the loci of power. The conformists can be described as populist mobilizers who prefer a more traditional journalistic role - to disseminate public information.

The multiplicity of roles among investigative journalists and an arising conflict among them is caused by the consequence of broader processes in Ukrainian journalism, its post-Soviet legacy, and by difficult transformations over the last two decades. Ukrainian media culture is not clear-cut. Ukrainian journalists are becoming more interventionist, ${ }^{45}$ and, as a result, "a journalist [in Ukraine] is more than a journalist." 46 The professional culture of investigative journalists in Ukraine is like a mosaic that is still in search of a broad and widely accepted formula.

Observed from a professional and cultural point of view, investigative journalism in Ukraine is still in its initial stage. The effect of a more liberal media market and notable changes that took place on Euromaidan only accelerated the creation of divergent views on the values and roles of journalists. New challenges, such as the hybrid information

\footnotetext{
43 Horbyk, "In Pursuit of Kairos," 16.

44 Horbyk, "In Pursuit of Kairos," 6, 18.

45 Budivska and Orlova, "Between Professionalism and Activism," 150-53.

46 Dovzhenko, "Ne boiatysia siroho vovka."
} 
war against Ukraine and the transformations of journalism worldwide, pose other worrying obstacles for the development of a universal journalism culture.

Additionally, the multiplicity of roles shows another dilemma: investigative journalism is in search of its place in society. Some investigative journalists tend to associate themselves with traditional journalism, others with activism, or even politics. So, what is the true nature of contemporary investigative journalism? Association is an important factor in journalism, that, as a template, defines what is written and transmitted. Objective journalism has its problems, however, journalism that loses its nature and mutates into politicized journalism is a much more questionable practice.

This study has been limited by a small sample group of journalists, namely of investigative journalists. This is one of the reasons why, on the one hand, more journalists identify themselves with the two first types of role conception, namely populist mobilizer and watchdog, and, on the other hand, why they don't support the opportunist facilitator role. Therefore, to understand what the role conceptions of other groups of Ukrainian journalists are, a broader and more universal study based on survey methodology is necessary. When conducted, it will be possible to compare our results with the role conceptions of journalists who work in other genres of journalism.

There is also a need to study the roles of journalists, including investigative journalists, from other post-Soviet states and the post-socialist states of Central and Eastern Europe.

To conclude, investigative journalists in Ukraine usually identify themselves with populist mobilizer and watchdog roles, sometimes with a critical change agent role. However, these roles may sometimes conflict. Additionally, journalists also tend to mix journalism with activism when they take a more active stance toward corruption and other issues they expose. Revealing the hidden truth, exposing corruption and other wrongdoings, controlling the government, and, to some extent, punishing wrongdoers are the key roles of investigative journalists in Ukraine in the years following the Euromaidan.

\section{Bibliography}

Budivska, Halyna, and Dariya Orlova. "Between Professionalism and Activism: Ukrainian Journalism After the Euromaidan." Kyiv-Mohyla Law and Politics Journal 3 (2017): 137-56.

Cassidy, William P. "Variations on a Theme:The Professional Role Conceptions of Print and Online Newspaper Journalists." Journalism \& Mass Communication Quarterly 82.2 (2015): 264-8o. https://doi.org/10.1177/107769900508200203.

Christians, Clifford G., et al. Normative Theories of the Media:Journalism in Democratic Societies. Chicago: University of Illinois Press, 2009.

Cohen, Bernard C. Press and Foreign Policy. Princeton, New Jersey: Princeton University Press, 1963. 
Coronel, Sheila S. "Corruption and the Watchdog Role of the News Media." In Public Sentinel: News Media and Governance Reform, edited by Pippa Norris, 111-37. Washington, D.C.: World Bank, 2010.

Deuze, Mark. "What is Journalism? Professional Identity and Ideology of Journalists Reconsidered." Journalism 6.4 (2005): 442-64. https://doi.org/ $10.1177 / 1464884905056815$.

Donsbach, Wolfgang. "Journalists' Role Perception." In The International Encyclopedia of Communication, edited by Wolfgang Donsbach, 2605-10. Oxford, UK; Malden, MA: Wiley-Blackwell, 2008.

Donsbach, Wolfgang, and Thomas E. Patterson. "Political News Journalists: Partisanship, Professionalism, and Political Roles in Five Countries." In Comparing Political Communication: Theories, Cases, and Challenges, edited by Frank Esser and Barbara Pfetsch, 251-70. New York: Cambridge University Press, 2004.

Dovzhenko, Maryna. "Ne boiatysia siroho vovka: hromadianskyi mediaaktyvizm v Ukraini [Not to be Afraid of a Grey Wolf: Civic Media Activism in Ukraine]." School ofJournalism at the Ukrainian Catholic University, December 15, 2015. http:// web.archive.org/web/2016o121102942/http://journalism.ucu.edu.ua/programhighlights $/ 4615 /$.

Dovzhenko, Otar. "Ukrainski media siohodni: z haremu v bordel [Ukrainian Media Today: From Harem to Brothel].” Detector Media, May 26, 2008. https://detector. media/withoutsection/article/386o2/2008-05-26-ukrainski-media-sogodni-zgaremu-v-bordel/.

Dyczok, Marta. "Do the Media Matter? Focus on Ukraine." In Media, Democracy and Freedom. The Post-Communist Experience, edited by Marta Dyczok and Oxana Gaman-Golutvina, 17-41. Bern: Peter Lang AG, 2009.

Hanitzsch, Thomas. "Populist Disseminators, Detached Watchdogs, Critical Change Agents and Opportunist Facilitators: Professional Milieus, the Journalistic Field and Autonomy in 18 Countries." International Communication Gazette 73.6 (2011): 477-94. https://doi.org/10.1177/1748048511412279.

Hanitzsch, Thomas, et al. "Mapping Journalism Culture Across Nations." Journalism Studies 12.3 (2011): 273-93. https://doi.org/10.1080/1461670X.2010.512502.

Hanitzsch, Thomas. "Professional Identity and Roles of Journalists." Oxford Research Encyclopedia of Communication, October 26, 2017. https://doi.org/10.1093/ acrefore/9780190228613.013.95.

Hanitzsch, Thomas. "Deconstructing Journalism Culture: Toward a Universal Theory." Communication Theory 17 (2007): 367-85.

Hanitzsch, Thomas. "Mapping Journalism Culture: A Theoretical Taxonomy and Case Studies from Indonesia." Asian Journal of Communication 16.2 (2006): 169-86.

Horbyk, Roman. "In Pursuit of Kairos: Ukrainian Journalists Between Agency and Structure During Euromaidan." Baltic Worlds 12.1 (2019): 4-19. 
Janowitz, Morris. "Professional Models in Journalism: The Gatekeeper and the Advocate." Journalism Quarterly 52.4 (1975): 618-26. https://doi. org/10.1177/107769907505200402.

Johnstone, John W. C., Edward J. Slawski, and William W. Bowman. "The Professional Values of American Newsmen." Public Opinion Quarterly 36.4 (1972): 522-40. https://doi.org/10.1086/268o36.

Kholodenko, Olena. "Nataliia Ligachova: 'Samaia opasnaia zavisimost segodnia dlia zhurnalista - eto zavisimost ot sobstvennykh ubezhdenii' [Nataliia Ligachova: 'The Most Dangerous Addiction for a Journalist Today is Dependence on Their Own Beliefs]." Detector Media, December 20, 2017. https://detector.media/community/ article/133264/2017-12-20-natalya-ligacheva-samaya-opasnaya-zavisimostsegodnya-dlya-zhurnalista-jeto-zavisimost-ot-sobstvennykh-ubezhdenii/.

Kocher, Renate. "Bloodhounds or Missionaries: Role Definitions of German and British Journalists." European Journal of Communication 1 (1986): 43-64.

Krzyżanowski, Michał. "Values, Imaginaries, and Templates of Journalistic Practice: A Critical Discourse Analysis." Social Semiotics 24 (2014): 345-65.

Kvit, Serhiy. "Ukraine Has Never Given Up and Never Will." Kyiv Post, February 1, 2020. https://www.kyivpost.com/article/opinion/op-ed/serhiy-kvit-ukraine-has-nevergiven-up-and-never-will.html.

Lewis, Seth C. "The Tension Between Professional Control and Open Participation: Journalism and its Boundaries." Information, Communication, and Society 16.6 (2012): 1-31.

Mancini, Paolo. "Political Complexity and Alternative Models of Journalism." In DeWesternizing Media Studies, edited by J. Curran and Myung-Jin Park, 234-35. London; New York: Routledge, 2000.

Mellado, Claudia, and Arjen van Dalen. "Changing Times, Changing Journalism: A Content Analysis of Journalistic Role Performances in a Transitional Democracy." The International Journal of Press/Politics 22 (2017): 244-63.

Nayyem, Mustafa. "Ladno, davaite seriozno...[Okay, Let's Take it Seriously...]." Facebook, November 21, 2013. https://www.facebook.com/Mefistoff/posts/1020117728026o15 1 ?stream_.

Neil, Jebril. "Is Watchdog Journalism Satisfactory Journalism? A Cross-National Study of Public Satisfaction With Political Coverage.” Working paper, Reuters Institute for the Study of Journalism, University of Oxford, 2013. Accessed March 15, 202O. https://reutersinstitute.politics.ox.ac.uk/sites/default/files/2018-01/Is\%2O Watchdog\%2oJournalism\%2oSatisfactory\%2oJournalism.pdf.

Orlova, Dariya. "Ukrainian Media After the EuroMaidan: In Search of Independence and Professional Identity." Publizistik 61.4 (2016): 441-61.

Ryabinska, Natalya. "Media Capture in Post-Communist Ukraine." Problems of PostCommunism 61.2 (2014): 46-6o.

Salovaara-Moring, Inka. "Beyond East and West: Alternative Spheres of Journalism, Capitalism and Public." In Manufacturing Europe: Spaces of Democracy, Diversity 
and Communication, edited by Inka Salovaara-Moring, 97-116. Gothenburg: Nordicom, 2009.

Schmidt, Vivien. "Discursive Institutionalism: The Explanatory Power of Ideas and Discourse." Annual Review of Political Science 11.1 (2008): 303-26.

Shoemaker, Pamela J., and Stephen D. Reese. Mediating the Message: Theories of Influences on Mass Media Content. New York: Longman, 1996.

Van Dalen, Arjen, Claes H. de Vreese, and Erik Albaek. "Different Roles, Different Content? A Four Country Comparison of the Role Conceptions and Reporting Style of Political Journalists." Journalism 13.7 (2012): 903-22. https://doi. org/10.1177\%2F1464884911431538.

Vos, Tim. "Journalistic Role Conception: A Bridge Between the Reporter and the Press." Paper presented at the International Communication Association (ICA) Conference, New York, May 2005.

Waisbord, Silvio. WatchdogJournalism in South America. New York: Columbia University Press, 2000.

Willnat, Lars, David H. Weaver, and Jihyang Choi. "The Global Journalist in the TwentyFirst Century: A Cross-National Study of Journalistic Competencies." Journalism Practice 7.2 (2013): 163-83. https://doi.org/10.1080/17512786.2012.753210.

Weaver, David H., Lars Willnat, and G. Cleveland Wilhoit. "The American Journalist in the Digital Age: Another Look at U. S. News People." Journalism \& Mass Communication Quarterly 96.1 (2019): 101-3o. https://doi.org/10.1177\%2F1077699018778242.

\section{(2)}

Oleksandr Yaroshchuk is a $\mathrm{PhD}$ candidate in Mass Communications and a senior lecturer at the Mohyla School of Journalism (National University of Kyiv-Mohyla Academy), in the process of preparing a dissertation on the status of investigative journalism in Ukraine. He received his master's degree in journalism from the National University of Kyiv-Mohyla Academy. In 2019, Oleksandr Yaroshchuk was a visiting researcher at the Friedrich Schiller University Jena and at Tampere University. His research interests include media transformations in post-Soviet countries, journalism culture and media, the theory and practice of investigative journalism, journalists' role perceptions, and democratic processes in Eastern Europe. 